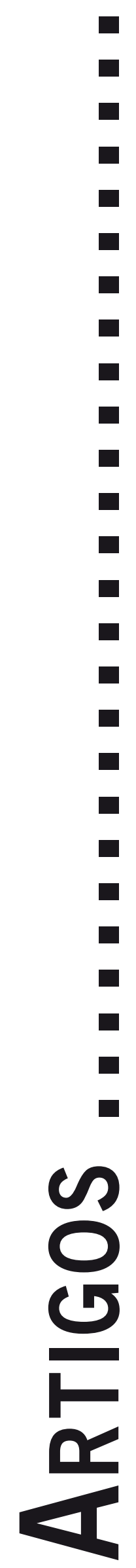




\title{
A ESCUTA FENOMENOLÓGICA COMPROMETIDA PELA ÓTICA RELIGIOSA DE UMA GESTALT-TERAPEUTA
}

\author{
Phenomenological Listening Committed by Religious Perspective of a Gestalt Therapist \\ La Escucha Fenomenológica Comprometida por la Perspectiva Religiosa de un Terapeuta Gestaltista
}

Jackeline Paulla Tavares

Celana Cardoso Andrade

\begin{abstract}
Resumo: A experiência religiosa, inerente ao homem, pode permear a relação terapeuta-cliente. O gestalt-terapeuta deve estar preparado para investigar, a partir de uma escuta atentiva, a experiência única do cliente. O presente trabalho tem como objetivo evidenciar o conflito da terapeuta ante a incompatibilidade de seus valores morais-religiosos e dos valores existenciaisfenomenológicos da sua ciência. Ele se divide em três partes: a primeira, trata do embasamento teórico referente à experiência religiosa e à abordagem gestáltica; a segunda, refere-se à apresentação dos três participantes; e a terceira, apresenta a relação entre a teoria e os dados colhidos. Conclui-se que valores incompatíveis interferem em uma escuta fenomenológica, por isso a importância da suspensão dos valores e crenças do profissional.
\end{abstract}

Palavras-chave: Experiência Religiosa; Gestalt-terapia; Epoché; Conflito.

\begin{abstract}
A religious experience is inherent to man and can permeate the therapist-client relationship. The gestalt therapist must be prepared to investigate the unique experience of the client, from an attentive listening. This paper aims to highlight the conflict of the therapist before the incompatibility of their moral values and also the religious and existential-phenomenological values of their science. It is divided into three parts: the first one deals with the theoretical background on the religious experience and the Gestalt approach; the second refers to the presentation of the three participants; and the third shows the relation between theory and data collected. The conclusion is that incompatible values interfere with a phenomenological listening. For this reason the suspension of the values and beliefs of the professional is important.
\end{abstract}

Keywords: Religious Experience; Gestalt-therapy; Epoché; Conflict.

Resumen: La experiencia religiosa, inherente al hombre, puede traspasar la relación terapeuta-cliente. El terapeuta gestáltico debe estar preparado para investigar, a partir de una escucha atenta, la experiencia única del cliente. El objetivo de este trabajo es evidenciar el conflicto del terapeuta ante la incompatibilidad de sus valores morales/religiosos y de los valores existenciales fenomenológicos de su ciencia. Por lo cual, este trabajo se divide en tres partes: la primera, trata del basamento teórico referente a la experiencia religiosa y el abordaje gestáltico; la segunda, se refiere a la presentación de tres participantes; y la tercera, presenta la relación entre la teoría y los datos recolectados. Se concluye que valores incompatibles interfieren en la escucha fenomenológica, por eso, es importante que el profesional suspenda sus valores y creencias.

Palabras-clave: Experiencia Religiosa; Terapia Gestáltica; Epoché; Conflicto.

Atualmente, há uma constante busca de significado do ser humano e uma crescente discussão sobre a importância da dimensão espiritual no homem e é relevante que uma ciência como a psicologia aborde tais questões existenciais. No entanto, como a busca de sentido é inerente ao homem, o próprio psicólogo também vivencia tal experiência, muitas vezes por meio da religião. $\mathrm{O}$ profissional precisa estar atento para suspender seus $a$ prioris ao aproximar do mundo vivido do cliente, principalmente nos relatos de experiências muito próximas ou contrárias aos seus valores.

\section{A Experiência Religiosa}

Qual o sentido da minha vida? Como tenho existido? Qual o meu destino? Qual o sentido do mundo? Para
Mahfoud \& Massimi (1999) e Prado (1999), esses tipos de perguntas, que emergem no cotidiano da pessoa, referem-se ao sentido da existência, da natureza do homem e subentendem um vazio existencial. Rigacci (2005) observa que o desejo humano é a revelação desse vazio, o qual denuncia a presença de uma ausência, e, em decorrência, o homem, desde a mais tenra idade, questiona acerca de sua existência, buscando uma outra dimensão da realidade.

Vergote (2001a) assinala que, antes de Cristo, o reconhecimento dos deuses, mediante ritos e festas, era tão necessário quanto trabalhar e se defender dos inimigos. A modernidade, por sua vez, caracteriza-se, segundo o autor, pela "progressiva dissociação entre a religião e (...) a política e a organização social, que passaram a ser assuntos propriamente humanos, independentes da religião" (p. 14). Já na contemporaneidade, os homens, em princí- 
pio, "têm o direito e a possibilidade cultural e social de crer ou de não crer" (p. 15).

Rigacci (2005), porém, acentua a importância da religião, a qual tem como essência "a relação homem-Deus, homem-homem e homem-mundo" (p. 53), uma experiência em que o homem vivencia a privação e busca incessantemente o apoio religioso, com sua "capacidade de dar nomes aos entes presentes e simbolizar o que está ausente. A religião, como instituição, por meio dos símbolos, apresenta-se como uma fala daquilo que está ausente" (p. 53).

Por sua vez, Pinto (2007) define a religião como

um sistema de orientação e um objeto de devoção; os símbolos religiosos evocam sentimentos de reverência e de admiração, além de estarem, em geral, associados a um ritual; na religião, encontramos também sentimentos, atos e experiências humanas em relação ao que se considera sagrado. (p. 9)

Goto (2004) entende a vivência religiosa como inerente ao ser-do-homem, e a institucionalização da religião, apesar dos tempos que se passaram, muitas vezes, ainda implica a imposição de regras, que ditam, conforme cada crença, o que deve ser seguido e o que é considerado pecado. E, para o homem religioso, o não-cumprimento dessas regras pode causar culpa, medo, conflitos, já que, segundo Vergote (2001b), "o pecado é teologicamente uma doença da alma e psicologicamente um mal-estar" (p. 131).

Apesar dos medos, das culpas e imposições, Teixeira (2005) considera que a religião também pode provocar uma mudança de conduta na vida que envolve toda a pessoa, e ser também um fator preventivo. Farris (2005) complementa que a religião fornece a ordem e a coerência à totalidade de vida. Assim, Pinto (2007) explica que "a religião tanto pode ser vista como uma fonte de força para as pessoas como pode também ser um refúgio para a fraqueza" (p. 10).

Nesse sentido, não se pode considerar que uma ciência que tem o homem como objeto de estudo, exclua o seu aspecto espiritual. Para Giovanetti (1999), ignorá-lo "é passar ao largo do problema e deixar escapar uma oportunidade de ajudar o cliente a se compreender melhor" (p. 95). O psicólogo precisa estar aberto a tal experiência humana, não devendo nem doutrinar em seu consultório nem ignorar a religião.

\section{A Psicologia e a Religião}

A psicologia, como toda ciência, viveu momentos em que negligenciou a experiência religiosa, situação que tem sofrido modificações. Valle (2005) destaca que a abertura da psicologia à religiosidade não surgiu do nada, tem uma longa história, que é descrita por ele da forma que se segue.
Segundo esse autor, na psicologia norte-americana, Stanley Hall (1844-1924) e William James (1842-1910) valorizaram, em seus estudos, o tema da religião. Porém, com o surgimento de outras correntes psicológicas, como o behaviorismo e a psicanálise, começou-se a negligenciar a religião, "pois a julgavam de pouca importância heurística e escassa ou nula serventia prática" (Valle, 2005, p. 86). O marxismo e a ênfase organicista também contribuíram para "o exílio a que o religioso havia sido condenado nas ciências humanas em geral e, muito especialmente, nas psicoterapias" (p. 86), ocorrendo uma repressão do fundamento espiritual da existência humana.

Valle (2005) considera ainda que, aos poucos, o cenário que rejeitava o religioso foi progressivamente substituído por outro, mais aberto. O espiritual deixou de ser entendido como uma alienação, ignorância ou mera projeção do desejo e do instinto.

Valle (2005) explica que psicólogos eminentes, como Carl Jung (1875-1961), Erik Erikson (1902-1994), Viktor Frankl (1905-1997), Gordon Allport (1897-1967), Erich Fromm (1900-1980), Abraham Maslow (1908-1970), e tantos outros, contribuíram teoricamente para evitar a hostilidade da psicologia em relação a tudo o que dissesse respeito ao religioso. $\mathrm{O}$ mesmo autor, porém, destaca que muitos profissionais ainda ignoram a importância de abordar este aspecto nos seus estudos ou na sua prática clínica. No entanto, a atitude de não-restrição abre a possibilidade de o psicólogo ver seu objeto de estudo por prismas inusitados.

Baseado no que foi explanado sobre a característica de o ser humano questionar sobre sua existência, surge a seguinte indagação: como pode uma ciência, como a psicologia, que estuda o homem, negar a dimensão espiritual?

Tal ciência atualmente apresenta um campo diversificado, no qual os temas podem ser abordados por perspectivas diferentes (Hockenbury \& Hockenbury, 2002). É importante na psicologia uma abordagem que perceba o homem como um ser bio-psico-social-espiritual e que almeje atingir a essência de suas experiências, sempre singulares, buscando ir às coisas mesmas.

O presente trabalho apresenta a Gestalt-terapia como prática clínica que, conforme Yontef (1998), focaliza a experiência do paciente e não ignora a teoria, pois "o terapeuta precisa ter uma quantidade substancial de conhecimentos sobre os seres humanos em geral; porém, precisa sempre se esforçar para apreciar profundamente a experiência única da pessoa sentada à sua frente" (Hycner, 1995, p. 28).

\section{A Gestalt-terapia e a Fenomenologia}

A Gestalt-terapia existencial-fenomenológica foi fundada por Frederick Perls (1893-1970), Laura Perls (19051990) e colaboradores, no ano de 1951, e é uma "combi- 
nação de numerosas correntes filosóficas e terapêuticas de diversas fontes, tanto européias como americanas" (Ginger \& Ginger, 1995, p. 33).

Em rápidas pinceladas, para melhor compreender suas raízes, apresenta-se uma caracterização de algumas correntes que as fundamentam. O humanismo evidencia o homem como centro, valorizando-o (Ribeiro, 1999). O existencialismo enfatiza a responsabilidade do homem em relação a suas escolhas (Ribeiro, 1999). A fenomenologia investiga e descreve a experiência, mediante a epoché, que permite chegar às coisas mesmas, à essência do fenômeno, o que se mostra à consciência (Ribeiro, 1999). A teoria organísmica propõe ver o homem como um todo, incluindo o contexto e as relações, que são enfatizados pela teoria de campo, que considera o homem inserido em um campo maior (Ribeiro, 1999). Por fim, a dialógica valoriza a relação, o entre, utilizando a escuta como sua fundamental ferramenta (Hycner, 1995).

O objetivo principal da Gestalt-terapia é "tornar os clientes conscientes (aware) do que estão fazendo, como podem transformar-se e, ao mesmo tempo, aprender a aceitar e valorizar-se" (Yontef, 1998, p. 16).

Entretanto, para o terapeuta ajudar o paciente a tornarse aware do seu pensar, agir e sentir, ele precisa voltar-se para a experiência do cliente. O homem, como ser singular, atribui, de maneira única, diferentes significados às suas experiências. A Gestalt-terapia utiliza como método clínico a atitude fenomenológica, que é a investigação e descrição da experiência como ela se apresenta à consciência daquele que experiencia; é a apreensão segundo o referencial daquele que vive o fenômeno.

Assim, para perceber a realidade do cliente como ela é significada por ele, o psicoterapeuta deve utilizar-se da epoché, recurso da fenomenologia, a fim de atingir a essência do fenômeno - que, na psicoterapia, é o vivido pela pessoa atendida. Para Goto (2004), realizar a epoché "consiste em nos ausentarmos por completo dos julgamentos que temos (...). Só desta maneira que é possível chegarmos à reflexão clarificadora do fundamento último e absoluto e deixar surgir o sentido de ser de algo" (p. 27). Dartigues (1992) destaca que fazer epoché não se trata de negar o que se conhece a respeito do objeto, mas simplesmente assumir uma rigorosa disciplina metodológica de modo a permitir que o novo apareça.

\section{O Papel do Gestalt-terapeuta Fenomenológico}

De acordo com Hycner (1995), o cliente busca a terapia para encontrar alguém que o compreenda, ou que pelo menos faça um esforço para compreendê-lo. $\mathrm{O}$ terapeuta então é solicitado a responder a diversas formas de ser-nomundo, e ele o fará entrando no mundo do cliente.

Para Rodrigues (2000), apesar de pacientes irem à terapia com um discurso claro, as palavras são escutadas por uma outra pessoa (psicoterapeuta), e a compreensão subjetiva de cada um ao escutar é imprevisível. O método fenomenológico permite investigar a experiência que se mostra.

O olhar atentivo do psicoterapeuta diante do fenômeno que se mostra "permite que as possibilidades únicas e ricas do cliente floresçam" (Hycner, 1995, p. 115), e sua tarefa é "descobrir e entender qual o significado de um evento para aquela pessoa em particular" (Hycner, 1995, p. 118). Uma vez que tenha suspendido seus pressupostos, o psicoterapeuta precisa ser capaz, no aqui e agora, de rastrear experiências e significados percebidos pelo cliente que ocorrem a cada momento. Para Cardoso (2002), "é fundamental o terapeuta abandonar a postura de certeza sobre seu cliente e assumir aquele questionamento, buscando atualizar sempre com a pessoa o seu está sendo" (p. 66). Ribeiro (1999) assinala ainda que o profissional "não impõe ações ou rumos; ele organiza na ação do outro, colhe no pensar, na fala e no agir do outro a atmosfera que ele vive e na qual se aprisionou” (p. 31).

Para Hycner (1995), "o terapeuta não pode entrar verdadeiramente no mundo do cliente e estar 'presente', a menos que esteja disposto a suspender seus pressupostos, preconceitos e crenças", só assim será permitida "a entrada no mundo e nos conceitos mais significativos $d a$ pessoa" (p. 115). A fenomenologia denomina epoché tal atitude.

O terapeuta, a fim de ampliar a consciência do paciente (awareness), deve colocá-lo "o tempo todo, diante de sua experiência imediata, tanto do ponto de vista da consciência quanto da emoção" (Ribeiro, 1999, p. 29). Assim, é de suma importância que o profissional se doe à relação, em uma atitude presente, atentiva, valorizando o outro na diferença, sem impor seus valores (epoché).

Hycner (1995) destaca que é papel do terapeuta estar atento "à experiência do cliente, mas simultaneamente atento à sua própria existência" (p. 114). Para tanto, o mesmo autor ressalta que entrar no mundo do outro pode implicar a perda da própria perspectiva, por isso, constitui desafio para o terapeuta "não só apreciar total e profundamente a experiência do cliente, mas também manter seu próprio centro diante de experiências divergentes e até conflitantes" (p. 122).

É imprescindível o psicoterapeuta manter seu próprio centro diante de experiências próximas às dos clientes, e escutas o outro e a si mesmo, em um movimento constante (Ribeiro, 1999). Yontef (1998) fala da atitude de confirmar, como um "posicionar-se, tanto quanto possível na experiência do outro, sem julgar, analisar ou interpretar, e simultaneamente resguardar o sentido de sua própria presença distinta" (p. 19).

O terapeuta confronta-se, a todo o momento, com "questões da vida de outras pessoas que talvez não estejam resolvidas em sua própria vida (...) Isso lhe permite empatizar profundamente com as dificuldades do cliente" (Hycner, 1995, p. 30). O psicoterapeuta é seu próprio instrumento na terapia, ele "precisa ser mantido afinado, 
para responder aos ritmos constantes mutáveis do encontro" (Hycner, 1995, p. 30). Suas feridas, suas crenças não podem ser mantidas como foco na terapia, e, se o for, haverá inúmeras conseqüências para o atendimento.

O gestalt-terapeuta é o seu instrumento, contudo, como lembra Yontef (1998), apesar de a Gestalt-terapia enfatizar a liberdade para fazer o atendimento com espontaneidade, vivacidade e criatividade, ela também exige do profissional a responsabilidade de saber o que está fazendo e de buscar melhores opções.

Com base no exposto, deparando-se com algum cliente que apresenta questões sobre experiências religiosas, não cabe ao gestalt-terapeuta fazer juízos de valor sobre estas experiências e "sim ajudar a esclarecer os fatores, estruturas e processos de natureza psicológica presentes no que o paciente experimenta" (Valle, 2005, p. 96). O terapeuta não deve ignorar o evento religioso, nem doutrinar a respeito, apenas investigá-lo como um fenômeno inerente a qualquer ser humano.

O presente trabalho, com base na abordagem gestáltica, tem como objetivo evidenciar o conflito que a terapeuta pode experimentar ante a incompatibilidade entre seu sistema de valores morais-religiosos e os valores existenciais-fenomenológicos da sua ciência, conflito que compromete sua escuta fenomenológica.

O tema foi escolhido em razão de chegarem à terapia, clientes com crença religiosa definida, passando por conflitos da mesma natureza da psicoterapeuta que iniciava seus atendimentos. Este encontro evidenciou à psicoterapeuta a dificuldade de suspender suas crenças e poder atuar sem a prioris, guiando-se pelo referencial do cliente, segundo o preceito fenomenológico da abordagem.

\section{Participantes}

O presente estudo teve como participantes três clientes: um do sexo feminino (Luciana) e dois do sexo masculino (Caio e Pedro). Todos os três nomes são fictícios por uma questão ética.

\section{Luciana}

Luciana, 37 anos, irmã mais velha de dois irmãos (casados), é solteira, mora com os pais e pertence à classe média baixa. Atualmente trabalha como vendedora. Apesar de já ter procurado diversos psiquiatras foi a primeira vez que Luciana se submeteu ao atendimento psicológico. Sua queixa inicial era insônia, vontade de morrer, falta de sentido em sua vida, vergonha de sair de casa por conta de tentativa de suicídio em fevereiro de 2008. Iniciou o processo psicoterapêutico um mês após a tentativa de suicídio.

\section{A vivência da experiência religiosa de Luciana}

Luciana, católica praticante, sente-se culpada pela tentativa de suicídio, por considerar pecado tal ato.
O fato ocorreu um mês antes de iniciar o processo psicoterápico.

Ao procurar a terapia, Luciana queixava-se que nada mais fazia sentido, e o que a impedia de uma nova tentativa de suicídio era o medo de não ser perdoada por Deus. A terapeuta, ao ouvir a culpa da cliente, percebeu que concordava com ela ao considerar pecado a tentativa de suicídio. A confluência entre as duas interferiu no seu atendimento, deixando a terapeuta interrompida.

\section{Caio}

O outro participante é Caio, 27 anos de idade, tem um irmão casado e uma irmã solteira. É solteiro, mora com os pais, pertence à classe social baixa e é homossexual. Recém-formado em Administração e, atualmente trabalha como chefe de recursos humanos. Nunca havia feito psicoterapia e decidiu procurar o atendimento psicoterápico por sentir-se extremamente inseguro para encarar o mercado de trabalho e experimentar muita culpa em razão da homossexualidade.

\section{A vivência da experiência religiosa de Caio}

Caio é evangélico. Assumiu sua homossexualidade no início de 2007, acredita que está pecando e por isso preferiu se afastar, momentaneamente, de sua igreja, que não aceita essa orientação sexual. Afirma que sofre muito, e que não devia ser assim; deveria desejar uma mulher, como prescreve a Bíblia.

A terapeuta, por sua vez, segue uma doutrina que também condena o homossexualismo e concorda com Caio sobre a importância de viver com base em seus princípios religiosos.

\section{Pedro}

O terceiro e último participante é Pedro, 18 anos, mora com os pais e três irmãs, é solteiro, pertence à classe média baixa e atualmente cursa Direito. Nunca havia participado de um trabalho psicoterapêutico. Procurou o Cepsi por indicação de sua mãe, que já fazia psicoterapia. O cliente queixa-se da própria passividade, da culpa de não ajudar sua mãe tanto financeiramente quanto nas atividades diárias, já que ela sustenta a família, porque seu pai está desempregado. Permaneceu no processo durante cinco meses, totalizando quinze sessões, com duração de cinqüenta minutos cada.

\section{A vivência da experiência religiosa de Pedro}

Pedro é católico praticante. Em suas sessões sempre retoma a importância de sua religião, a qual está muito presente em sua vida. Porém, Pedro, constantemente aponta a angústia entre seguir somente a Deus ou seguir o mundo. Para ele, é hipocrisia entrar no mundo competitivo do trabalho, que deixa a pessoa cada vez mais individualista, e, ao mesmo tempo pregar que é religioso, que segue as normas da Bíblia, dentre elas, o coletivismo. 
A terapeuta, apesar de não concordar com a incompatibilidade entre Deus e mundo, apontada por Pedro, compartilha com ele a idéia da importância de seguir a Deus.

\section{Resultados e Discussão}

De acordo com a metodologia clínica da Gestalt, que utiliza a investigação fenomenológica da vivência do sujeito e cuja natureza relacional com o cliente baseia-se nos princípios dialógicos buberianos, o terapeuta deve suspender seus próprios conceitos, ou seja, utilizar-se da epoché. Esta atitude de suspensão tem o intuito de conseguir a descrição dos fenômenos vividos tal como ocorrem na experiência, independentemente de quaisquer preconceitos, pressupostos ou teorias explicativas. No entanto, a terapeuta, que na ocasião iniciava sua carreira profissional com estagiária, encontrou grande dificuldade em manter esta atitude durante os atendimentos, quando os clientes abordavam a vivência de conflitos entre suas necessidades ou experiências pessoais e suas crenças relacionadas a questões religiosas. A terapeuta observou, em suas discussões de caso com a supervisora, que sua atuação era diferente quando trabalhava conflitos com temas não-religiosos. Ficou claro que a redução fenomenológica era dificultada nos temas religiosos, tão próximos aos seus.

A consciência dessa dificuldade é fundamental, pois como lembra Forghieri (2004) "o psicólogo também deve ser objeto de suas investigações e reflexões; e então as perguntas tanto se voltam para seus clientes como para ele próprio. O modo como tenta compreender e ajudar outras pessoas é, basicamente, o modo como tenta compreender-se" (p. 3).

A fim de elucidar a escuta comprometida da terapeuta no processo de ajuda, em virtude do conflito entre sua religiosidade e os princípios livres de a prioris da fenomenologia, serão mostrados trechos de sessões nas quais os participantes trataram de questões que remetiam a suas crenças religiosas e a conduta correspondente da terapeuta nessas situações.

Pedro, durante suas sessões, queixou-se de sua passividade diante do questionamento que o atormentava: "Qual caminho a seguir: Deus ou o mundo?"

Segue-se o diálogo entre Pedro e a terapeuta.

P. (...) Eu fico me questionando o que será que é certo.

T. Você consegue me descrever o que é certo para você?

P. Consigo. É basicamente ser bom com os outros, ajudar o próximo, respeitá-lo, é tipo seguir os mandamentos, entende? Mas aí vem aquelas coisas que eu quero crescer, ser bom no que eu faço, um bom advogado, aí vem logo a questão da competição, acho que não dá para ser os dois, ou é uma coisa ou outra
(...). Eu quero ser diferente, ajudar o próximo, ser bom para o próximo, pensar menos em mim, igual era Jesus. Claro que não consigo ser igual! [sorrisos], mas seguir seu exemplo. Tenho que ficar me controlando (...) eu tento crer que há pessoas boas que chegaram em uma situação financeira estável e que não foram ambiciosas a ponto de se tornar desumanas [silêncio]. (...) Mas como eu ainda não conheço a melhor forma de agir eu fico angustiado, não ajo, se é para agir mal então eu não ajo.

T. Como você sente falando dessas coisas?

P. Confuso. Tem muita coisa que ainda eu não cheguei a questionar, então tem muita coisa que eu não sei responder direito.

Percebeu-se ser evidente o conflito ético de Pedro, que leva a sério os mandamentos da Igreja, almejando seguir o exemplo de Cristo, dedicando-se a seu próximo e à sua comunidade.

Essa meta existencial o deixa constantemente atribulado, pois a concebe como antitética, em virtude das pressões do mercado de trabalho, da competição desenfreada e da falta de solidariedade humana no espaço mundano. A terapeuta, na sua primeira intervenção, nota que buscou voltar-se para a experiência do cliente. Afinal, para Ribeiro (1999), "é função da psicoterapia colocar a pessoa, a todo instante, diante de si mesma" (p. 27), pois a experiência do cliente é singular, única.

Na segunda intervenção a terapeuta percebe que atuou de forma convencional. Apenas perguntou o que Pedro sentia quando deveria ter indo além, focando sua atenção no movimento de Pedro, que, por conta do conflito ético entre seguir um estilo de vida ou outro, fica paralisado, dando um sentido à queixa inicial - sua passividade. A terapeuta considera que essa sua atitude 'superficial' pode ter ocorrido devido a um déficit de presença, por tratarse de um tema perturbador para ela, já que, em sua experiência, ela busca constantemente relacionar os dois mundos, que para Pedro são incompatíveis.

Caio, com um discurso introjetado, afirma viver em pecado, por ter relações com outros homens, e por isso faz a seguinte negociação: irá aproveitar a homossexualidade mais três anos, ao completar trinta anos, fará um acordo com Deus e seguirá os princípios bíblicos do matrimônio. Em uma sessão com Caio estabelece-se o diálogo que se segue.

T. Você considera pecado, seus pais não acham certo, mas não consegue ficar longe do Júlio por amá-lo! Como se sente com isso?

C. É ruim, eu sinto um vazio enorme, choro! O meu problema está sendo esse: “E Deus?”. Não quero fugir dos meus princípios. Por isso, um dos projetos que eu tenho é ficar nessa vida até os meus trinta anos. Vou curtir mesmo, mas com trinta anos eu quero arrumar uma mulher para mim. 
T. Você está me falando que hoje você é homossexual, mas daqui a alguns anos você pretende se assumir como heterossexual. Como você se sente, mesmo sabendo que é homossexual, fazendo planos para futuramente se casar com uma mulher?

C. Está na Bíblia que o homem tem que constituir sua família, e eu quero isso para mim, não quero viver no pecado, não quero acabar sozinho, sem nada, sem filho. O nosso meio é muito estranho (...).

A terapeuta fez uma intervenção voltando-se para a experiência do cliente, descrevendo inicialmente o que fora mencionado por ele, confrontando-o com a pretensão de assumir um falso self.É papel do terapeuta investigar o significado daquilo que o cliente apresenta na sua fala (Ribeiro, 1999), já que seu fundamento existencial visa buscar o ser autêntico do cliente. Por isso, é importante a investigação fenomenológica, a qual almeja atingir a essência da experiência que deverá sempre ser assumida por aquele que experiencia. Contudo, Caio não responde a indagação da terapeuta! Evita o contato com a decisão inautêntica que diz querer assumir com o outro (no caso, sua futura parceira). Para a terapeuta fica evidente que ela deveria ter pontuado a evitação do cliente deixando a ele a responsabilidade de assumir ou não a resposta à sua questão.

Assim como Caio, Pedro também pretendia mudar sua vida completamente. Pedro tinha a intenção de seguir o sacerdócio, não por vocação, mas para resolver o conflito ético que vem sofrendo:

P. Tem na minha cabeça uma confusão de pensamentos sobre como eu quero guiar minha vida. A minha crença religiosa é cristã, quem orienta a gente é Cristo, Jesus, e tem toda uma doutrina que ensina sobre a vivência daqueles que querem o seguir... Eu fico assim, querendo saber como eu vou agir de agora em diante. Se eu vou seguir o que falam, ou se eu vou seguir o que a vida propõe para mim, que é um caminho...

T. O que a vida está propondo a você??

P. Estudar, arrumar um emprego, futuramente continuar estudando, fazer diversos cursos...

T. E o que seria ser guiado por Cristo?

P. [Silêncio] Buscar ajudar o próximo... Individualismo e coletivismo, entendeu.

T. Você estudar, se dedicar aos estudos é o individualismo e ajudar o próximo é o coletivismo, é isso?

P. É.

T. Para você não dá para juntar os dois?

$P$. Eu não estou conseguindo ver isso.

A terapeuta buscou investigar os significados atribuídos pelo cliente acerca de seus planos. Porém, está faltando a clareza do que, de fato, é para o cliente o individualismos e o coletivismo. Foi percebido que ele se refere ao conflito entre a atitude egocentrada, denominada individualismo, e o espírito comunitário.
No entanto, faltou a exploração vivencial desses conceitos, para a melhor compreensão da natureza da incompatibilidade sentida pelo cliente. Afinal, como Ribeiro (1999) explica, o homem, na sua singularidade, confere significados diferentes às diversas experiências, daí a importância do método fenomenológico de ir-às-coisas-mesmas, a fim acessar o sentido particular do sujeito do fenômeno.

O mesmo autor ainda assinala que "a pessoa humana é a medida de si mesma, sabe o que ela é, o que quer e para onde pretende ir" (p. 30). Com essa perspectiva, a psicoterapeuta tentou voltar-se para a experiência de Pedro, a fim, também, de que ele olhasse para si mesmo, para sua atitude de separar os dois estilos de vida, buscando alguma possibilidade de integração. A falta de compreensão clara da natureza do dilema foi o que impediu melhor awareness do experienciado.

No caso de Caio, que enfrenta o dilema sexual e os preceitos religiosos condenatórios dessa disposição, a terapeuta concorda com a incoerência entre os dois mundos, o que perturba a genuína escuta fenomenológica, como se pode perceber no diálogo com esse cliente.

C. Eu amo demais as coisas da Igreja, eu amo a Deus!! Nossa! se eu pudesse... Mas são duas coisas opostas, não adianta!! Eu já tenho em minha mente que Deus não reconhece o homossexualismo, não adianta! T. Como você fica falando que Deus não reconhece o homossexualismo e você assumindo que é homossexual?

C. [Chora] Eu acho ruim, fico pensativo, eu nunca fui uma pessoa pensativa! Eu sei que é pecado, mas não consigo deixar (...). Queria tanto que eles me aceitassem. Queria tanto estar mais próximo de Deus, como era antes!

Caio sofre por não ser aceito pela família e também ao não se sentir aceito por Deus. A terapeuta, por sua vez, fez uma intervenção que intensifica ainda mais a culpa que ele sente por suas práticas homossexuais. Essa intensificação foi percebida pela terapeuta no tom de voz com que ela fez a intervenção. Ela corretamente focou a dor do cliente ao não se sentir reconhecido por Deus, porém, na última frase acentuou o fato de ele continuar suas relações homossexuais. Neste sentido, a acentuação da culpa deu-se pelo tom de voz usado pela terapeuta. A forma de indagação com um tom de voz acolhedor não teria essa significação dada na leitura, ou seja, não comunicaria a sensação de julgamento. Ribeiro (1999) explica que a atitude não avaliativa é componente essencial da escuta fenomenológica, e, também, uma forma de acolher o cliente.

Luciana, assim como Caio, também sente grande culpa religiosa. Na experiência de Luciana, sua tentativa de suicídio foi um desafio a Deus, o que a faz se sentir extremamente angustiada. Teixeira (2005) explica que o religioso acredita que o não-cumprimento das leis divinas 
ofende, desagrada e envergonha a Deus, o que pode explicar o conflito de Luciana, como se pode perceber em trechos de uma sessão.

L. (...) Ele não castiga por eu ter tentado suicídio, mas eu sinto que Ele está chateado comigo: "Poxa, eu te dei a vida!" [Emociona-se].

T. Qual a emoção que vem?

L. [Fala chorando] Ele está triste comigo! Eu não sou doente, não uso droga, não fui presa, sou normal e faço isso! Tem hora que eu penso que estou sendo castigada, mas não é castigo, é uma lição para eu aprender, que quem tira a vida é só Ele (...).

T. Como está sua relação com Ele?

L. [Chora] Tem dia que eu tenho vergonha, vergonha de ir à igreja, de falar com Ele, por tudo que eu fiz, que eu faço.

Luciana considera firmemente que Deus está chateado com ela por ter tentado tirar a própria vida, a qual, segundo sua crença, só Ele pode fazê-lo. No primeiro momento, a terapeuta notou que, corretamente, voltou-se para a emoção que estava presente. Cardoso (2002) explica que o terapeuta deve compartilhar com o cliente o que foi apreendido de sua fala, tanto no plano verbal quanto no não-verbal, "convidando-o a se perceber, a se escutar e a se reconhecer na própria fala, tanto no que é dito quanto no que é ocultado" (p. 63).

No entanto, no segundo momento, a terapeuta fez uma intervenção que fugiu ligeiramente do que a cliente estava dizendo. A terapeuta percebeu que havia defletido, justamente por concordar com a opinião da cliente, por considerar que Luciana devia permanecer naquela dor, já que pecara. Nesse sentido, a terapeuta buscou valorizar a relação da cliente com Deus, a qual, para a terapeuta, é de extrema importância.

Ainda no caso de Luciana, seu medo da vida além da morte - considera que não irá para o céu - a impede de tentar o suicídio novamente. A terapeuta, que também acredita que tal ato é pecaminoso, aproveitou para, de uma forma sutil, mostrar para a cliente a importância da fé, no diálogo que se segue.

L. Ultimamente eu estou muito nervosa, preocupada, ansiosa, cheia de mágoa, com o coração pequenininho, o que me faz pensar em fazer besteiras de novo, vou lá, converso com Ele. Fico até três horas lá com Ele, isso me deixa MUITO mais leve!

T. Você percebe que sua fé a impede de tentar suicídio de novo?

L. [Chora] Impede. Com certeza!!! Eu tenho muita fé em Deus. Eu só não faço de novo porque sei que irei magoá-lo novamente, e sei também que quem faz isso não é perdoado, não vai para o céu. O problema é que, às vezes, tanta coisa ruim cai em cima de mim que parece que eu fico sem fé, sem esperança... Me deixando mais sem fé, sem esperança.
Na primeira intervenção, a terapeuta, que acredita no potencial transformador e preventivo da oração, notou que acentuou para a cliente que sua fé a impede de tentar suicídio nesse atual momento de sua vida.

Para Rodrigues (2000), o terapeuta é uma força no campo, por isso seu olhar atentivo tem grande influência no desvelar do sujeito. Na sessão de Caio, o olhar atentivo sofreu uma interrupção evidente. A terapeuta deu-se conta mais tarde de que ele foi o cliente que mais mobilizou seu próprio dilema religioso. Sua intervenção tentou adaptar o participante ao suposto modelo de cristandade, o que se mostra, sobretudo na sessão que se segue.

C. Agora que estou de férias quero cuidar de mim (...) Quando eu for marcar minhas consultas, eu vou marcar só com médicas, eu prefiro ser atendido por mulher. Quando eu estava na Igreja, eu adorava ouvir palavras das mulheres, mas não tinha amizade porque não tinha jeito, né?

T. Interessante que você sempre se lembra de fatos marcantes de quando você estava na Igreja, dá a impressão que a Igreja para você ainda é muito forte!!! [tom enfático da intervenção!].

Fica evidente para a terapeuta que ela elegeu, na fala do cliente, somente a referência à Igreja, deixando a comunicação nova e essencial sobre sua priorização da figura feminina. E ela o fez enfatizando, no seu tom de voz, a intervenção selecionada na fala de Caio, dirigindo o que seria discutido na sessão e não aquilo que era referência do cliente. Na posterior discussão do caso, a terapeuta percebeu que a questão da Igreja não era figura para o cliente naquela sessão, e sim sua relação de admiração pelas mulheres, mas parece que a volta à Igreja era crucial para a terapeuta! A terapeuta, nesse caso, teve, segundo Cardoso (2002), uma escuta seletiva, a qual não permitiu o acesso à novidade experiencial do cliente.

No caso de Luciana, que compartilha vergonha e medo por ter ofendido à Deus, a terapeuta também não atentou para esse sentimento e fez uma intervenção alheia à experiência dessa participante.

L. [Chora] Tem dia que eu tenho vergonha, vergonha de ir à Igreja, de falar com Ele, por tudo que eu fiz, que eu faço. Parece que eu vou até lá e Ele vai brigar comigo. Eu estou com medo. Estou indo todos os dias, mas não está adiantando. Eu sinto que eu estou sendo criticada por Ele, o que parece que deixa minha fé abalada.

T. Isso faz com que você sinta raiva dele Ele?

L. Não, Não. Eu tenho raiva é de mim, eu tenho ódio é de mim. Eu devia ter morrido, não é justo eu desafiálo desse jeito e ainda querer voltar para Ele e querer conversar ainda, rezar ainda. Eu tenho é vergonha. Eu sei que ele não está me castigando, mas eu sinto no meu eu que ele está me castigando. 
A terapeuta incluiu, em sua intervenção, a palavra raiva, que não estava na fala da cliente, nem de forma encoberta! Posteriormente, deu-se conta de que ela é que temia a raiva da cliente pela figura divina! Assim, a terapeuta tentou uma inclusão frustrada, pois não captou os sentimentos da cliente, ou seja, havia entre elas um déficit de presença da terapeuta, resultante do seu próprio temor religioso. Ribeiro (2006) afirma que se o terapeuta não estiver presente, dificilmente ajudará o cliente.

A fim de elucidar a importância da presença da terapeuta, o seguinte trecho da sessão de Caio é extremamente relevante. Sua culpa constante faz que ele considere que, atualmente, está passando por tribulações por ter saído da Igreja para assumir sua condição homossexual. Essa decisão implica, para ele, a perda da ajuda de Deus em sua vida, como aparece no diálogo travado entre ele e a terapeuta.

C. Fico pensando: "Será que é porque eu saí da Igreja?". É tanta luta, tanto problema, tanta perseguição...

T. Você está me falando que você atribui seus problemas atuais ao fato de ter saído da Igreja, é isso?

A terapeuta usou a confirmação, reassumindo a atitude de presença essencial à escuta fenomenológica. Ela percebeu com tom de voz compreensivo, a dor do cliente. Esta intervenção mostra como se torna vacilante a conduta da profissional, perdendo e recuperando sua atitude fenomenológica, em vista da dupla vinculação existencial com princípios diferentes.

No caso de Luciana, a terapeuta apenas repetiu o que fora dito. A cliente relatou que sentia mais calma ao conversar com Deus, e que, ao sair da igreja, se sentiu bem mais leve.

P. (...) As únicas pessoas que eu converso é com você e com Deus. Se eu não venho aqui, eu vou à igreja, eu converso, eu choro... A única pessoa que pode me ajudar e acalmar meu coração é Deus, só Ele!! Não tem amigos, namorado, família que seja melhor que Ele!

L. Você está me dizendo que ir à igreja, conversar com Deus... [a terapeuta busca compreender a fala da cliente].

P. ...Acalma! Ultimamente eu estou muito nervosa, preocupada, ansiosa, cheia de mágoa, com o coração pequenininho!... Vou lá, converso com Ele. Fico até três horas lá com Ele, isso me deixa muito mais leve!

A terapeuta, envolvida com a cliente, buscou entender o que fora dito por ela, o que, por si só, já constitui um bom fazer terapêutico. Contudo, passou-lhe despercebido que poderia realçar que, além de Deus, Luciana também estava conseguindo conversar com uma pessoa humana, a sua pessoa. Esta pontuação poderia despertar a awareness da cliente para o poder do encontro inter-humano!

\section{Conclusão}

Nesse trabalho, evidenciam-se algumas dificuldades enfrentadas pelo terapeuta religioso, ao abordar, em suas sessões, temas próximos às suas experiências religiosas e ao conflito experienciado por ele mesmo. Vivendo esse processo, a terapeuta, em seu processo de supervisão, deu-se conta de que, em alguns momentos, submeteu-se aos dogmas da sua Igreja, abandonando os princípios fenomenológicos e dialógicos quando as duas posições eram conflitantes na sessão. O penoso conflito sofrido pela psicoterapeuta entre preceitos religiosos e fenomenológicos incompatíveis paralisou, como a seu cliente Pedro, o seu fazer terapêutico, encerrando o processo, muitas vezes, justamente no ponto em que o cliente já se encontrava antes da sessão.

Porém, lidar com esse conflito não é uma tarefa simples! Falar em aceitar o cliente como um todo, como um ser bio-psico-socio-espiritual não implica uma mera teoria, mas uma atitude de profunda conversão epistêmica que necessariamente resultará no abandono de qualquer ideologia que aprisione o ser naquilo que é visado por esta ideologia, sem o respeito fenomenológico por aquilo que ele está sendo e pelo seu surpreendente - e não controlável - vir a ser.

A observância dos princípios clínicos gestálticos, ou seja, aqueles que exigem a suspensão dos pressupostos, dos valores e opiniões na relação de ajuda, invocando a presença genuína a cada sessão, com uma escuta confirmadora do vivido pelo outro, pressupõe um treinamento a longo prazo, aliado à forte predisposição libertária da pessoa do terapeuta. A terapeuta teve essa atitude diminuída, mas não eliminada, pois, em muitos momentos, ela conseguiu, de forma intencional e disciplinada, pesquisar aquilo que os clientes experienciavam e manter um contato dialógico com eles.

É evidente que, em algumas passagens, a religião da terapeuta, muitas vezes, não lhe permitiu realizar a epoché, ou seja, a suspensão completa do juízo a respeito de algo, como foi referido, já que suas regras morais semelhantes às dos participantes, superavam, nestes momentos, a sua atitude fenomenológica. Seu embasamento teórico e sua conversão epistêmica, não foram ainda suficientes para que ela conseguisse, de forma persistente, suspender seus valores nos momentos em que vinha à tona o conflito entre sua moral religiosa e vivência subjetiva do cliente. Nesta situação existencial ambígua, a terapeuta não conseguia posicionar-se na experiência do falante, nem realizar a confirmação ou a inclusão por um déficit de presença, e, algumas vezes, priorizando a moral religiosa, afastava-se da experiência humana do cliente.

Essa superação ideológica é realmente delicada! Exige profunda maturidade emocional, profissional e humana, que a terapeuta iniciante ainda não logrou alcançar em um patamar satisfatório e que é absolutamente compreensível. A preparação do gestalt-terapeuta para, em seu consultório, abordar temas dessa natureza, que envolvam 
valores conflitantes, só se dá respeitando a temporalidade da existência, que, aliada a muito estudo e vivência profissional e pessoal, pode propiciar a maturidade essencial para o confronto com essa crise ética com a qual se depara a terapeuta.

A terapeuta entende que, a despeito dos referidos erros na condução das sessões, o processo como um todo revelou bons resultados, o que se deve à atitude intencional e consciente de acolhimento da vivência do outro, e a busca, embora vacilante, de compreensão aliada à atmosfera permissiva, facilitou a revelação da pessoa do cliente na sua autenticidade. A atitude dialógica de fundo, mesmo falhando em algumas intervenções técnicas, mas sempre visando o encontro, se tornou um elemento fundamental no gradativo bem-estar pessoal dos clientes. A predisposição do terapeuta, assimilada ao seu treinamento acadêmico, foi promovendo a abertura dos clientes à awareness do seu ser aqui-agora e do caminho que ainda estão escolhendo trilhar, isto é, a abertura à consciência da própria responsabilidade pelas escolhas e decisões que estão se dando, como a abertura à própria aceitação do seu ser em situação de dilema que, afinal, é o objetivo dessa abordagem!

\section{Referências}

Cardoso, C. L. (2002). A escuta fenomenológica em psicoterapia. Revista do VIII Encontro Goiano da Abordagem Gestáltica Relação Dialógica: a cura pelo encontro, 8, 61-69.

Dartigues, A. (1992). O que é a fenomenologia? São Paulo: Editora Moraes.

Farris, J. R. (2005). Aconselhamento psicológico e espiritualidade. Em M. M. Amatuzzi (Org.), Psicologia e espiritualidade (pp. 161-172). São Paulo: Paulus.

Forghieri, Y. C. (2004). Psicologia fenomenológica: fundamentos, método e pesquisa. São Paulo: Pioneira Thomson Learning.

Giovanetti, J. P. (1999). O sagrado e a experiência religiosa na psicoterapia. Em M. Massimi \& M. Mahfoud (Orgs.), Diante do mistério: psicologia e senso religioso (pp. 87-96). São Paulo: Loyola.

Ginger, A. \& Ginger, S. (1995). Gestalt: uma terapia do contato. São Paulo: Summus.

Goto, T. A. (2004). O fenômeno religioso: a fenomenologia em Paul Tilich. São Paulo: Paulus.

Hycner, R. (1995). De pessoa a pessoa: psicoterapia dialógica. São Paulo: Summus.

Hockenbury, D. H. \& Hockenbury, S. E. (2002). Descobrindo a psicologia. São Paulo: Manole.

Massimi, M \& Mahfoud, M. (1999). Senso religioso: dinamismo da experiência, desafio para a psicologia. Em M. Massimi \& M. Mahfoud. (Orgs.), Diante do mistério: psicologia e senso religioso (pp. 11-13). São Paulo: Loyola.
Pinto, E. B. (2007). Gestalt-terapia de curta duração para clérigos católicos: elementos para a prática clínica. Tese de Doutorado não publicada, Pontifícia Universidade Católica de São Paulo, São Paulo.

Prado, A. (1999). Arte como Experiência Religiosa. Em M. Massimi \& M. Mahfoud (Orgs.), Diante do mistério: psicologia e senso religioso (pp. 17-32). São Paulo: Loyola.

Ribeiro, J. P. (1999). Gestalt-terapia de curta duração. São Paulo: Summus.

Ribeiro, J. P. (2006). Vade-mécum da Gestalt-terapia: conceitos básicos. São Paulo: Summus.

Rigacci, G. (2005). A experiência religiosa e o encontro humano. Em M. M. Amatuzzi (Org.), Psicologia e espiritualidade (pp. 49-58). São Paulo: Paulus.

Rodrigues, H. E. (2000). Introdução à gestalt-terapia: conversando sobre os fundamentos da abordagem gestáltica. Petrópolis: Vozes.

Teixeira, F. (2005). O potencial libertador da espiritualidade e da experiência religiosa. Em M. M. Amatuzzi (Org.), Psicologia e espiritualidade (pp. 13-30). São Paulo: Paulus.

Valle. J. E. R. (2005). Religião e espiritualidade: um olhar psicológico. Em M. M. Amatuzzi (Org.), Psicologia e espiritualidade (pp. 83-107). São Paulo: Paulus.

Vergote, A. (2001a). Necessidade e desejo da religião na ótica da psicologia. Em G. J. Paiva (Org.), Entre necessidade e desejo: diálogos da psicologia com a religião (pp. 9-24). São Paulo: Loyola.

Vergote, A. (2001b). Processos psicológicos - vergonha, sentimento de culpa - e sentido bíblico do pecado, em particular em Romanos 7. Em G. J. Paiva (Org.), Entre necessidade e desejo: diálogos da psicologia com a religião (pp. 127-157). São Paulo: Loyola.

Yontef, G. M. (1998). Processo, diálogo e awareness: ensaios em Gestalt-terapia. São Paulo: Summus.

Jackeline Paulla Tavares - Psicóloga, graduada pela Universidade Católica de Goiás, especializanda em Gestalt-terapia pelo Instituto de Treinamento e Pesquisa em Gestalt-terapia de Goiânia (ITGT/UCG). E-mail: jackeline_tavares@hotmail.com

Celana Cardoso Andrade - Psicóloga, especialista em Psicologia Clínica, Gestalt-terapeuta, formada pelo Instituto de Treinamento e Pesquisa em Gestalt-terapia de Goiânia (ITGT). Professora do Curso de Psicologia da Universidade Federal de Goiás, professora do Curso de Especialização do ITGT. Organizadora dos Encontros Goianos da Abordagem Gestáltica. Editora associada da Revista da Abordagem Gestáltica. Mestre em Psicologia Clínica pela Universidade Católica de Goiás (UCG). Psicoterapeuta na Alter - Consultórios de Psicologia. E-mail: celana@terra.com.br.

Recebido em 09.09.08 Primeira Decisão Editorial em 16.04.09 Aceito em 20.08.09 